\title{
Thyroid Hormone Replacement Therapy: Three 'Simple' Questions, Complex Answers
}

\author{
Antonio C. Bianco Sabina Casula \\ Division of Endocrinology, Diabetes and Metabolism, University of Miami Miller School of Medicine, Miami, Fla., USA
}

\begin{abstract}
Key Words
Hypothyroidism $\cdot$ Thyroid hormone $\cdot$ Deiodination $\cdot$ Combined therapy $\cdot$ Levothyroxine $\cdot$ Liothyronine $\cdot$ Gene polymorphism $\cdot$ Desiccated thyroid
\end{abstract}

\begin{abstract}
Current guidelines recommend that hypothyroid patients should be treated with levothyroxine, which in the vast majority of the cases leads to resolution of the symptoms and normalization of serum free $\mathrm{T}_{4}\left(\mathrm{FT}_{4}\right), \mathrm{T}_{3}$ and TSH levels. However, a small group of hypothyroid patients remain symptomatic for neurocognitive dysfunction despite normal serum $\mathrm{FT}_{4}$ and $\mathrm{TSH}$, which could be explained by localized brain hypothyroidism. More than half of the $\mathrm{T}_{3}$ in the brain is produced locally via the action of the type II deiodinase $\left(D_{2}\right)$ and variability/defects in this pathway could explain the residual symptoms. If this rationale is correct, adding liothyronine to the replacement therapy could prove beneficial. However, with a few exceptions, several clinical trials failed to identify any beneficial effects of combined therapy. More recently, the results of a large clinical trial revealed a better neurocognitive outcome with combined therapy only in hypothyroid patients carrying a polymorphism in the $\mathrm{DIO} 2$ gene. This obviously needs to be confirmed by other groups but it is tempting to speculate that combined levothyroxine and liothyronine has a place in the treatment of hypothyroidism, for some.

Copyright ๑ 2012 European Thyroid Association Published by S. Karger AG, Basel
\end{abstract}

\section{KARGER}

Fax +41613061234

E-Mail karger@karger.ch

www.karger.com (c) 2012 European Thyroid Association

Published by S. Karger AG, Basel

2235-0640/12/0012-0088\$38.00/0

Accessible online at:

www.karger.com/etj
Hypothyroidism affects about $3.7 \%$ of the general population in the United States [1], reaching levels of up to $8 \%$ in areas with high prevalence of iodine deficiency [2]. At first sight, treatment for hypothyroidism, regardless of its etiology, seems quite straightforward. According to current guidelines the standard of care is treatment based on hormonal replacement therapy with daily administration of levothyroxine, the pro-hormone produced exclusively by the thyroid gland [3]. The rationale is that the deiodinases, thioredoxin-fold containing selenoenzymes that metabolize thyroid hormone and are present in multiple extrathyroidal tissues, activate thyroxine $\left(\mathrm{T}_{4}\right)$ and produce physiological amounts of the biologically active thyroid hormone, triiodothyronine $\left(\mathrm{T}_{3}\right)$ [4]. The observation that circulating levels of $\mathrm{T}_{3}$ and TSH can be normalized in levothyroxine-treated hypothyroid patients reassures physicians that euthyroidism is achieved and probably contributed for the replacement of porcine thyroid preparations by the synthetic form of levothyroxine currently used $[5,6]$. In fact, monitoring serum levels of TSH (and free $\mathrm{T}_{4}\left(\mathrm{FT}_{4}\right)$ ) became an integral part of the routine to follow the therapeutic efficacy of thyroid hormone replacement. However, despite normalization of these biochemical parameters, about $15 \%$ of those treated with levothyroxine replacement therapy alone do not achieve clinical euthyroidism and experience some level of psychological impairment [7].

Dr. Antonio C. Bianco

University of Miami Miller School of Medicine

1400 N.W. 10th Avenue, Suite 601

Miami, FL 33136 (USA)

Tel. +1 305243 5631, E-Mail abianco@med.miami.edu 
The persistency of a relatively small number of clinically symptomatic patients has led to an explosion of alternative treatment strategies, including the reawakening of desiccated porcine thyroid and development of new 'thyroid supplements' that take advantage of regulatory loopholes to avoid governmental oversight. This has created greater awareness in the medical community, with concerns gravitating mostly around two areas, namely (i) defining what is missing in our understanding of thyroid hormone signaling (transport across cell membranes and metabolism) that prevents us from developing a treatment strategy that is effective for $100 \%$ of the patients, and (ii) preventing the widespread usage of 'thyroid formulas' that in many cases leads to long-term subclinical or clinical thyrotoxicosis and their well-known consequences.

\section{Basic Principles of Thyroid Hormone Transport, Metabolism and Action}

$\mathrm{T}_{3}$ enters the target cells through a few specific thyroid hormone transporters, including monocarboxylate transporter (MCT)8, MCT10, and organic anion-transporting polypeptide 1C1 (OATP) [8]. Once inside the cells, $T_{3}$ gains access to the cell nucleus where it interacts with two forms of nuclear receptors (TR $\alpha$ and TR $\beta$ ); both TRs are unevenly distributed throughout the body, with virtually every cell expressing either one or both receptors. This modulates the expression of specific sets of $\mathrm{T}_{3^{-}}$ responsive genes, thus producing $\mathrm{T}_{3}$-dependent biological effects, e.g. positive cardiac chronotropism, bone resorption, acceleration of energy expenditure [9-11] (fig. 1).

In healthy adult individuals, about $80-90 \%$ of the extrathyroidal $\mathrm{T}_{3}$ is produced by deiodination of $\mathrm{T}_{4}$ via the type I $\left(D_{1}\right)$ and type II $\left(D_{2}\right)$ deiodinases $[12,13]$, which are widely expressed throughout extrathyroidal organs and tissues: $\mathrm{D}_{1}$, in liver and kidney, and $\mathrm{D}_{2}$, in the central nervous system, bone, skin, pituitary gland, brown adipose tissue and in minute amounts in skeletal muscle and heart $[14,15]$. Thus, there are two sources of $\mathrm{T}_{3}$ bound to tissue TR at any given time, i.e. (i) direct thyroid secretion or (ii) extrathyroidal deiodination of $\mathrm{T}_{4}[14,16]$. There is also a third deiodinase, $\mathrm{D}_{3}$, which can inactivate both $\mathrm{T}_{4}$ and $\mathrm{T}_{3}$ and is expressed mostly during embryonic life [17]; in healthy adults, $\mathrm{D}_{3}$ expression remains only in a handful of tissues, including brain, skin, heart and pancreatic $\beta$-cells $[14,18]$. However, during disease processes, $D_{3}$ expression can be enhanced severalfold or ectopi- cally activated in most tissues, including liver, skeletal muscle and heart via signals such as ischemia and/or hypoxia $[19,20]$.

\section{The First Question: Can Plasma and Tissue $\mathrm{T}_{3}$ Concentrations Be Normalized in Levothyroxine- Treated Hypothyroid Individuals?}

Serum $\mathrm{T}_{3}$ concentrations are expected to be normal in levothyroxine-treated hypothyroid individuals [21-23]. This would indicate that the deiodinase pathways are sufficient to normalize $\mathrm{T}_{3}$ levels in the plasma, provided that enough $\mathrm{T}_{4}$ is available. However, a recent large-scale cross-sectional study involving about 3,900 euthyroid volunteers and about 1,800 athyreotic patients kept on replacement therapy with levothyroxine indicates that serum $\mathrm{T}_{3}$ is consistently lower in the hypothyroid patients, although within the normal range [24]. Furthermore, in approximately $15 \%$ of these hypothyroid patients, serum $\mathrm{T}_{3}$ is not normalized despite normal serum TSH [24]. In addition, it seems that further increases in the dose of levothyroxine would not result in normalization of serum $\mathrm{T}_{3}$ without bringing serum TSH below the normal range. Of note, when all individuals are stratified as a function of their serum TSH, it is clear that for any given serum $\mathrm{TSH}$, the levothyroxine-treated hypothyroid patients exhibit significantly lower serum $\mathrm{T}_{3}$ [24].

One additional point to keep in mind is that, as opposed to $\mathrm{T}_{4}, \mathrm{~T}_{3}$ is mostly an intracellular hormone [14, $25]$. Yes, it is true that plasma and tissue $\mathrm{T}_{3}$ are at equilibrium at all times, but the sizes of both pools are not the same [14] and both $\mathrm{T}_{3}$ production and $\mathrm{T}_{3}$ degradation are intracellular events $[26,27]$. Deiodinase-mediated $\mathrm{T}_{3}$ production takes place inside the $\mathrm{T}_{3}$-target cells and thus in any given cell there is a chance that the TR-bound $\mathrm{T}_{3}$ was produced locally (within that very same cell) and found its way to the cell nucleus before exiting the cell or reaching the plasma (fig. 2). The odds of this happening vary from tissue to tissue and depend among other things on the local activity of the deiodinases. At the same time, $\mathrm{D}_{3}$-mediated $\mathrm{T}_{2}$ inactivation also takes place inside the cells and thus some of the $\mathrm{T}_{3}$ produced intracellularly might be degraded before reaching the plasma [27].

Thus, plasma $T_{3}$ level is a poor predictor of tissue $T_{3}$ concentration because it does not account for the intracellular production/inactivation of $\mathrm{T}_{3}$ via the deiodinase pathways. As a consequence, a normal serum $\mathrm{T}_{3}$ does not mean that the $\mathrm{T}_{3}$ content in all tissues is normal. In fact, a mouse with targeted inactivation of $\mathrm{D}_{2}\left(\mathrm{D}_{2} \mathrm{KO}\right)$ has nor- 


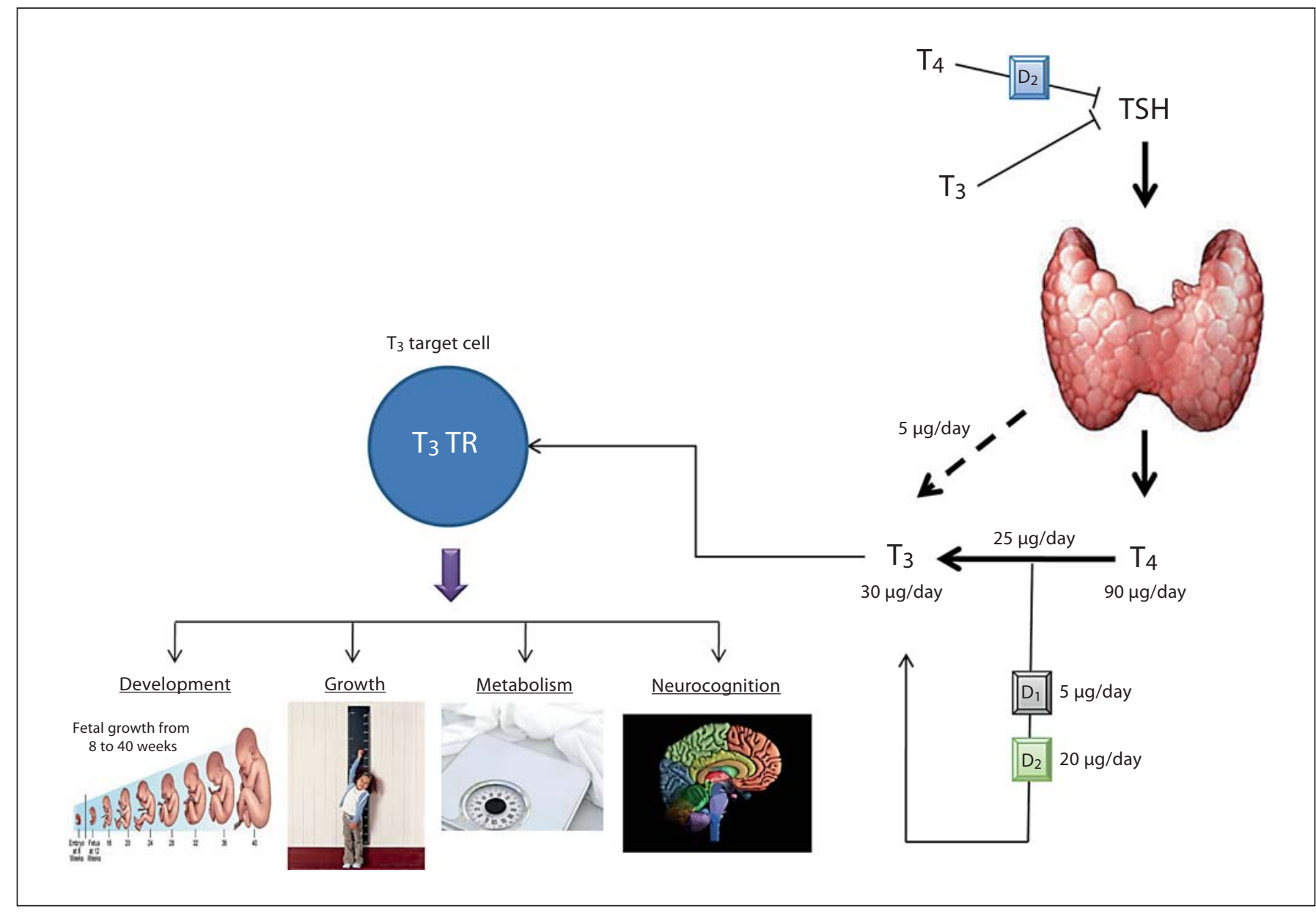

Fig. 1. Major aspects of thyroid hormone economy in healthy human subjects. The human thyroid produces approximately $90 \mu \mathrm{g}$ of $\mathrm{T}_{4}$ and $5 \mu \mathrm{g}$ of $\mathrm{T}_{3}$ daily; deiodinases $\left(\mathrm{D}_{1}\right.$ and $\left.\mathrm{D}_{2}\right)$ in extrathyroidal tissues are responsible for the production of approximately 25 $\mu \mathrm{g}$ daily. Plasma $\mathrm{T}_{3}$ enters thyroid hormone target cells and binds to TRs, changing the expression of $\mathrm{T}_{3}$-responsive genes. The subsequent changes in specific mRNA levels underlie the biological effects of thyroid hormone in various tissues during development, growth, metabolism and neurocognition. mal serum $\mathrm{T}_{3}$ levels, but its brain has only half as much $\mathrm{T}_{3}$ when compared to a normal mouse $[28,29]$. Even the mouse with combined $D_{1} / D_{2}$ inactivation exhibits normal serum $\mathrm{T}_{3}$, revealing a remarkable ability of the murine thyroid to upregulate $\mathrm{T}_{3}$ secretion when extrathyroi$\mathrm{dal}_{3}$ production is abolished $[30,31]$. A similar compensatory mechanism is expected to exist in humans, even though the human thyroid contributes much less to the daily $\mathrm{T}_{3}$ production. Thus, based on the mouse studies, it is very unlikely that patients with a 'defect' in the activating deiodinase pathway would be identified by a low serum $\mathrm{T}_{3}$. Remarkably, each of these animals has a normal serum $\mathrm{T}_{3}$ concentration and an increased serum $\mathrm{T}_{4}$ concentration. The elevations in serum $\mathrm{T}_{4}$ concentration may result from increased thyroidal secretion and/or decreased clearance, but in either case it is fascinating that the hypothalamic-pituitary-thyroid axis could be wired such that adjustments in serum $\mathrm{T}_{4}$ concentrations are made in order to maintain serum $\mathrm{T}_{3}$ concentrations [32]. Thus, it is tempting to speculate that serum $\mathrm{T}_{3}$ plays a critical role for some cells/tissues, perhaps the ones that do not exhibit significant deiodinase expression.

Only direct measurements of tissue $\mathrm{T}_{3}$ can answer the first question. Human tissues have been processed for $T_{3}$ content largely in the context of embryonic development or non-thyroidal illnesses [33-35], and not to address the 'first' question. Only studies in rats have addressed this point and the answer is a resonant 'no', i.e. extrathyroidal 


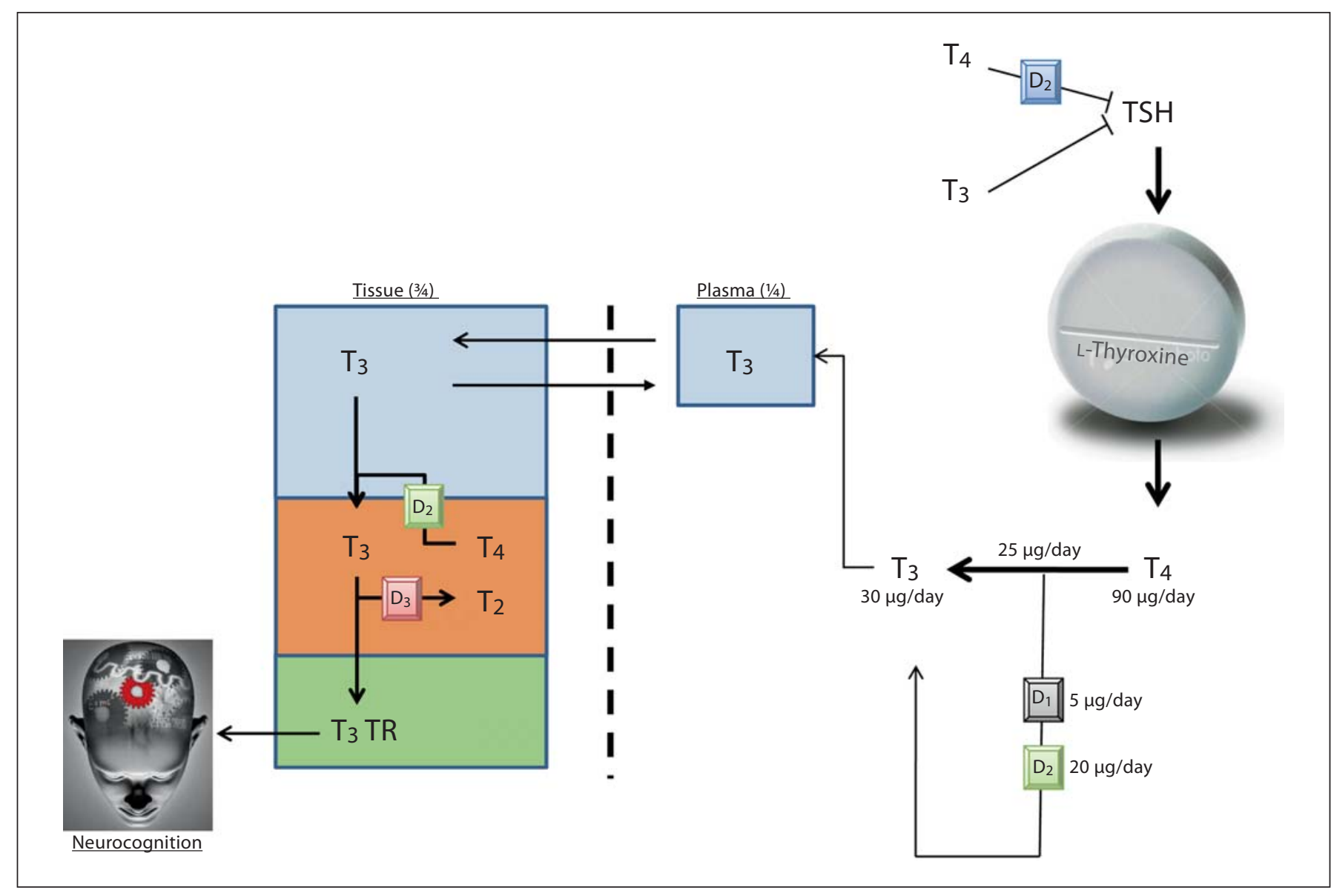

Fig. 2. Serum $T_{3}$ does not reflect brain $T_{3}$ levels. Three-quarters of the extrathyroidal $\mathrm{T}_{3}$ are located inside the cells. Despite the existing equilibrium between the plasma and tissue compartments, serum $\mathrm{T}_{3}$ does not faithfully reflect tissue $\mathrm{T}_{3}$ levels because plasma $T_{3}$ is not the only source of tissue $T_{3}$. In fact, substantial amounts of $\mathrm{T}_{3}$ are constantly produced and degraded inside specific cells and tissues, e.g. brain, pituitary gland or brown adipose tissue. metabolism of $\mathrm{T}_{4}$ does not normalize $\mathrm{T}_{3}$ content in most tissues [36]. However, prudence should be exercised while extrapolating rodent data to humans given that in rats the thyroidal contribution to $\mathrm{T}_{3}$ production is much larger than in humans, about $40 \%$ [14].

Nonetheless, when thyroidectomized rats were given a range of $\mathrm{T}_{4}$ doses $(0.2-8.0 \mu \mathrm{g} / 100 \mathrm{~g}$ b.w./day), no single dose of $\mathrm{T}_{4}$ was able to restore normal serum $\mathrm{TSH}, \mathrm{T}_{4}$ and $T_{3}$, as well as $T_{4}$ and $T_{3}$ in all tissues, or at least to restore $\mathrm{T}_{3}$ simultaneously in plasma and all tissues, except for the brain [36]. Indeed, central to our discussion is the fact that $\mathrm{T}_{3}$ content in the cerebral cortex and cerebellum was indeed normalized over a wide range of $\mathrm{T}_{4}$ doses, even by doses that were not sufficient to normalize serum TSH [36] (fig. 3). Thus, the normal rat brain (and probably the human brain as well) contains a highly efficient $\mathrm{D}_{2}$-me- diated mechanism that maintains its $\mathrm{T}_{3}$ concentration based on circulating $\mathrm{T}_{4}$. This agrees with the undeniable observation that about $85-90 \%$ of all patients with hypothyroidism on levothyroxine therapy alone are clinically and biochemically euthyroid, living normal healthy lives.

\section{The Second Question: Can a Variability/Defect in Thyroid Hormone Metabolism and/or Transport Affect Tissue $\mathrm{T}_{3}$ and Be Clinically Relevant?}

The fascinating aspect of the thyroid hormone transport across cell membranes combined with the deiodinase-mediated control of thyroid hormone action is that thyroid hormone signaling can be customized in a celland time-specific fashion, independently of serum $\mathrm{T}_{3}$ lev- 
Fig. 3. $\mathrm{T}_{3}$ and $\mathrm{T}_{4}$ levels in the cerebral cortex of hypothyroid rats infused with either $\mathrm{T}_{4}$ or $\mathrm{T}_{3}$. Note that in $\mathrm{T}_{4}$-infused rats, brain $\mathrm{T}_{3}$ normalizes at doses of $\mathrm{T}_{4}$ that do not normalize brain $\mathrm{T}_{4}$ levels. In addition, even at much higher $\mathrm{T}_{4}$ doses, brain $\mathrm{T}_{3}$ remains normal despite almost 4 -fold higher brain $\mathrm{T}_{4}$ levels. These observations highlight the critical role played by $\mathrm{D}_{2}$ and $\mathrm{D}_{3}$ in brain $\mathrm{T}_{3}$ homeostasis. Brain $\mathrm{T}_{3}$ content can also be normalized in $\mathrm{T}_{3}$-infused rats but only when the doses of infused $\mathrm{T}_{3}$ are approximately 3 -fold higher than the physiological replacement dose of $\mathrm{T}_{3}$ (about $0.3 \mu \mathrm{g} / 100 \mathrm{~g}$ b.w.). Modified from Escobar-Morreale et al. [36].

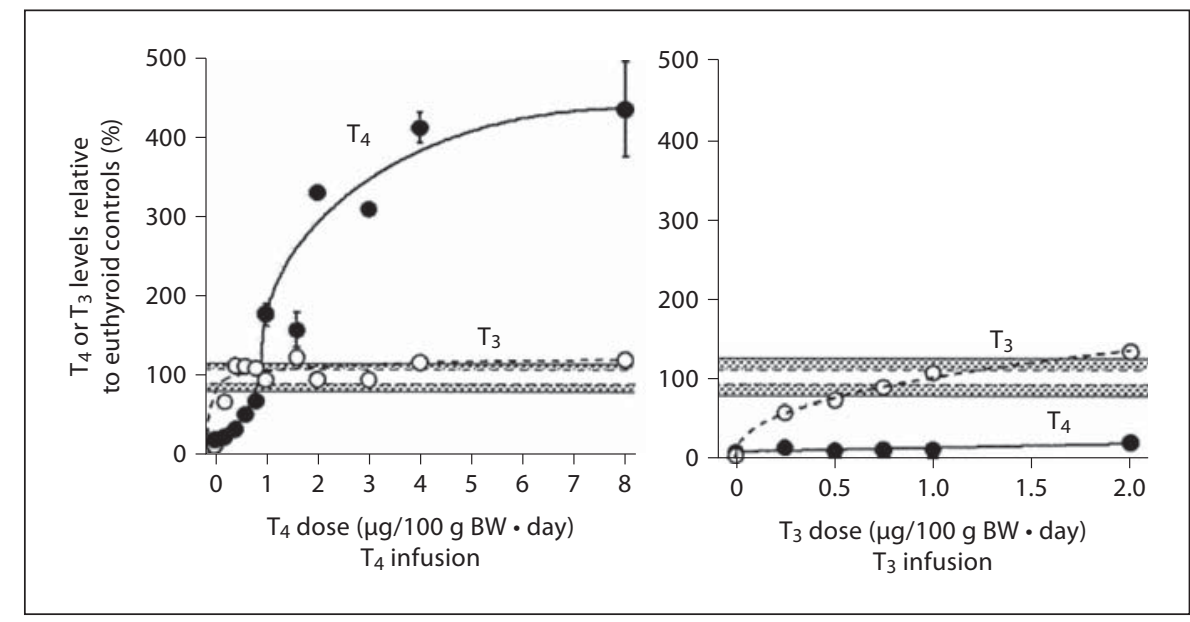

els $[8,11,16]$. In fact, in healthy adult individuals, serum levels of $\mathrm{T}_{4}$ and $\mathrm{T}_{3}$ are remarkably constant throughout life [37], unlike the $\mathrm{T}_{3}$ tissue content that can change rapidly in response to a number of developmental, metabolic and environmental cues [38]. Thus, it is logical to suppose that those patients who still experience neurocognitive impairment despite normalization of serum $\mathrm{TSH}, \mathrm{T}_{4}$ and $\mathrm{T}_{3}$ concentrations lack sufficient $\mathrm{T}_{3}$ in discrete brain areas due to a variability/defect in $\mathrm{D}_{2}$ and/or $\mathrm{D}_{3}$ pathways or thyroid hormone transport in the brain.

\section{Deiodinase Pathways}

Loss-of-function mutations have not been reported in any of the deiodinase genes. However, there is a report of two families in which 3 affected individuals exhibited transient growth retardation as a result of defective deiodinase expression due to a broad deficiency in selenoprotein synthesis [39]. This is an extremely rare syndrome that affects the synthesis of the three deiodinases. No data are available on whether such individuals exhibit alterations in tissue $\mathrm{T}_{3}$ content. However, because it is so rare, it is unlikely to impact significantly the present discussion.

A $D_{1}$-deficient mouse $\left(D_{1} K O\right)$ exhibits elevated serum levels of $\mathrm{T}_{4}$ and $\mathrm{rT}_{3}$, whereas serum TSH and $\mathrm{T}_{3}$ as well as several indices of peripheral thyroid status are unaffected $[40,41]$. However, $\mathrm{D}_{1}$ deficiency results in increased fecal excretion of endogenous iodothyronines suggesting that $\mathrm{D}_{1}$ may play a major role in limiting the impact of iodine deficiency [41]. At the same time, in humans a single nucleotide polymorphism rs2235544 of DIO1 gene has been identified [42] in association with an increase in free $\mathrm{T}_{3}$ and a decrease in $\mathrm{FT}_{4}$ and $\mathrm{rT}_{3}$ with no effect on serum
TSH levels. Similarly, carriers of the $\mathrm{D}_{1 \mathrm{~b}}-\mathrm{G} / \mathrm{T}$ (rs12095080) allele in elderly individuals had higher serum $\mathrm{T}_{3}$ and $\mathrm{T}_{3} /$ $\mathrm{rT}_{3}$ [43]. On the other hand, $\mathrm{D}_{1 \mathrm{a}}-\mathrm{C} / \mathrm{T}$ (rs11206244) carriers had higher serum $\mathrm{FT}_{4}$ and $\mathrm{rT}_{3}$, lower $\mathrm{T}_{3}$, and lower $\mathrm{T}_{3} /$ $\mathrm{rT}_{3}$ [43]. Despite biochemical differences in thyroid hormone serum levels, no data are available regarding tissue $\mathrm{T}_{3}$ levels and, more importantly, no clinical syndrome has been identified in carriers of these polymorphisms.

The $\mathrm{D}_{2} \mathrm{KO}$ mouse exhibits a rich phenotype based on alterations of tissue $\mathrm{T}_{3}$. The BAT [44-46], brain and pituitary gland [31, 47], skeleton [48], skeletal muscle [49, 50] and lungs [51] have all been extensively studied with major phenotypes attributed to deficient local generation of $\mathrm{T}_{3}$ via the $\mathrm{D}_{2}$ pathway. This of course opens the door for the existence of individuals with clinical syndromes caused by potential variability/defects in the $\mathrm{D}_{2}$ pathway. This is particularly true for the brain, where $\mathrm{T}_{3}$ content is dramatically affected by the $\mathrm{D}_{2}$ pathway $[31,52] . \mathrm{D}_{2}$ is responsible for more than half of the $\mathrm{T}_{3}$ present in the murine brain [52]. Accordingly, $\mathrm{D}_{2} \mathrm{KO}$ animals have half as much brain $\mathrm{T}_{3}$ content as their wild-type siblings [31], greatly supporting the idea that any interference in the $\mathrm{D}_{2}$ pathway could affect brain function and/or result in intellectual or cognitive symptoms.

A potentially relevant polymorphism in the $\mathrm{DIO} 2$ gene $\left(\mathrm{Thr} 92 \mathrm{AlaD}_{2}\right)$ has been described in about $15 \%$ of normal individuals [53] (fig. 4a, b). This was originally associated with insulin resistance and increased BMI [53], and subsequently with type 2 diabetes mellitus [54]. A recent case-control study with 1,057 type 2 diabetes patients and 516 non-diabetic subjects indicated that the frequencies of $\mathrm{D}_{2}$ Ala92Ala homozygosity were $16.4 \%$ $(n=173)$ versus $12.0 \%(n=62)$ in diabetic versus controls, 


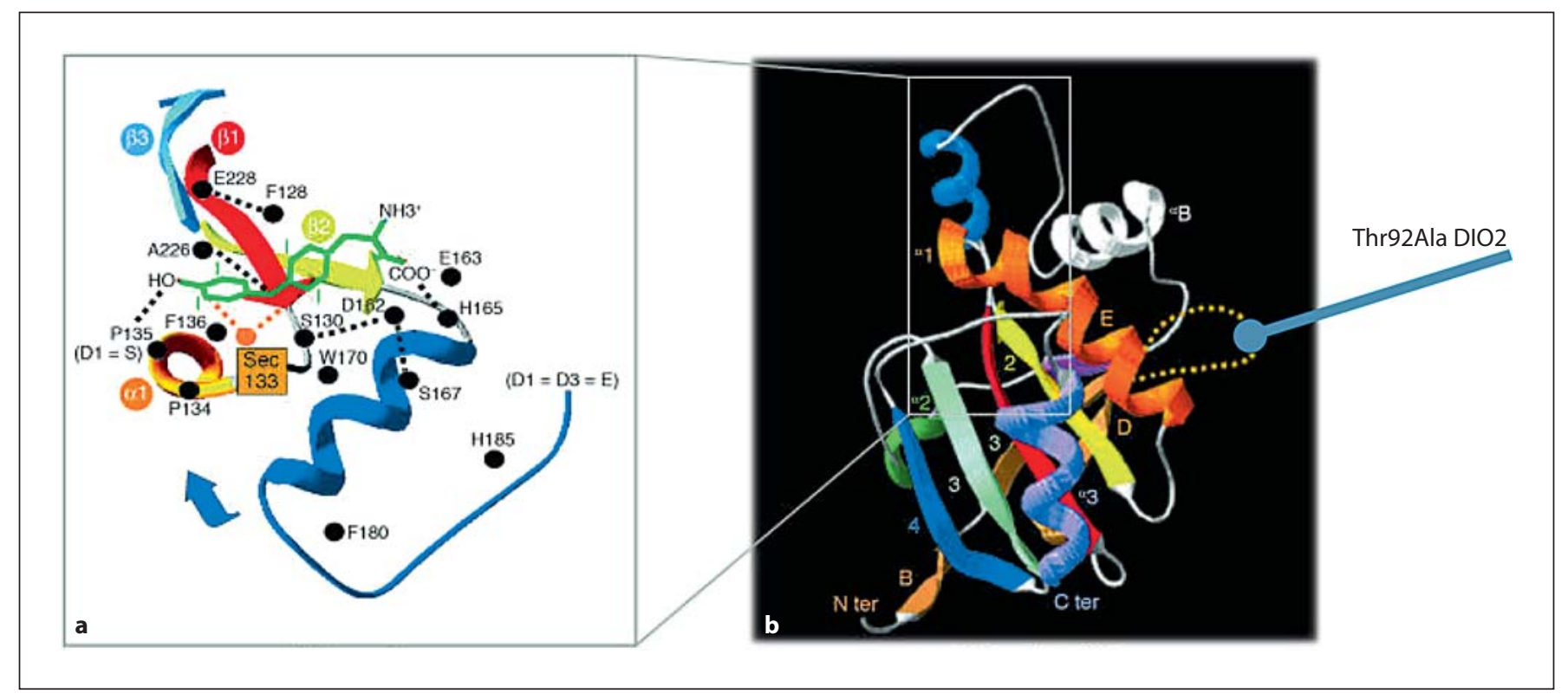

Fig. 4. 3D model of $\mathrm{D}_{2}$. a 3D model of the enzyme's active center is shown including the critical selenocysteine (Sec) at position 133. b Most of the enzyme's structure is shown including the 18-amino-acid loop that controls $\mathrm{D}_{2}$ half-life [101] and contains the Thr92Ala polymorphism. Modified from Callebaut et al. [102].

Table 1. Clinical features associated with the Thr92 $\mathrm{AlaD}_{2}$ polymorphism

\begin{tabular}{|c|c|}
\hline Association & Reference (first author) \\
\hline Insulin resistance and increased BMI & Mentuccia [53] \\
\hline \multirow[t]{2}{*}{ Type 2 diabetes } & Canani [54] \\
\hline & Dora [55] \\
\hline Mental retardation & Guo [56] \\
\hline Hypertension & Gumieniak [57] \\
\hline Osteoarthritis & Meulenbelt [58] \\
\hline Bipolar disorder & $\mathrm{He}[59]$ \\
\hline \multicolumn{2}{|l|}{ Clinical manifestations of thyrotoxic } \\
\hline Accelerated bone turnover & Heemstra [61] \\
\hline \multirow[t]{2}{*}{ Response to lung injury } & Barca-Mayo [51] \\
\hline & $\mathrm{Ma}[62]$ \\
\hline
\end{tabular}

respectively, resulting in an adjusted odds ratio of 1.41 (CI $95 \% 1.03-1.94, \mathrm{p}=0.03$ ) [55]. These data indicate that the homozygosity for $\mathrm{D}_{2}$ Thr92Ala polymorphism is associated with increased risk for type 2 diabetes, a conclusion that was supported by a meta-analysis including 11,033 individuals [55]. Today there is a much broader spectrum of diseases and conditions that have been associated with the Thr $92 \mathrm{AlaD}_{2}$ polymorphism, including mental retar- dation [56], hypertension [57], osteoarthritis [58], bipolar disorder [59], clinical course and myocardial remodeling [60], accelerated bone turnover [61], response to lung injury $[51,62]$, indicating that indeed this locus (and the Thr92 $\mathrm{AlaD}_{2}$ polymorphism) is clinically relevant (table 1).

Within the context of this discussion, the logical assumption is that the Thr92 $\mathrm{AlaD}_{2}$ polymorphism results in decreased $\mathrm{D}_{2}$ activity and thus localized tissue $\mathrm{T}_{3}$ deficiency and hypothyroidism. However, different groups have failed to detect differences in enzyme kinetics $\left(\mathrm{K}_{\mathrm{m}}\left(\mathrm{T}_{4}\right)\right.$ and $\left.\mathrm{V}_{\max }\right)$ of the $\mathrm{Thr} 92 \mathrm{AlaD}_{2}$ protein when transiently expressed in cultured cells [54,63]. A single study in tissue samples of individuals with the Thr92 $\mathrm{AlaD}_{2}$ polymorphism revealed decreased $\mathrm{V}_{\max }$ in biopsies of skeletal muscle and thyroid gland [54]. However, the data in skeletal muscle have since lost relevance given the subsequent discovery that special technical considerations are needed to correctly assay skeletal muscle $\mathrm{D}_{2}$ activity $[15,64]$, which were not considered in the said study [54]. Nevertheless, the reported decrease in thyroidal Thr92AlaD $\mathrm{V}_{\max }$ remains unchallenged, albeit not yet reproduced by other groups. Two studies in patients indirectly support the view that $\mathrm{Thr} 92 \mathrm{AlaD}_{2}$ is a catalytically less active enzyme: (i) higher doses of levothyroxine were needed to achieve target TSH levels in 191 thyroid- 
ectomized individuals carrying $\mathrm{Thr} 92 \mathrm{AlaD}_{2}$ polymorphism [65] and (ii) the finding that the Thr $92 \mathrm{AlaD}_{2}$ polymorphism is associated with a delayed $\mathrm{T}_{3}$ secretion in response to TRH stimulation [66]. Furthermore, all studies agree that patients with the Thr $92 \mathrm{AlaD}_{2}$ polymorphism have no alterations in all other thyroid function tests [63].

At the same time, it is important to highlight that the literature about the Thr92 $\mathrm{AlaD}_{2}$ polymorphism is controversial, with poor reproducibility amongst different studies [67-72]. This suggests that additional unidentified linkage factors such as ethnic background could play a significant role in the physiological and clinical relevance of the Thr92 $\mathrm{AlaD}_{2}$ polymorphism [71,73]. If future studies by other groups identify and isolate such factors and confirm the observation that $\mathrm{Thr} 92 \mathrm{AlaD}_{2}$ polymorphism limits $\mathrm{D}_{2}$ 's ability to produce $\mathrm{T}_{3}$, then 'yes' a variability/defect in the deiodination pathway that controls tissue $\mathrm{T}_{3}$ could be clinically relevant based on the multiple phenotypes associated with said polymorphism. At the time of this writing, other DIO2 polymorphisms have been reported, but their clinical relevance is even less well established [74].

The $\mathrm{D}_{3} \mathrm{KO}$ mouse exhibits the richest phenotype of all deiodinase $\mathrm{KO}$ animals, which stems from elevated tissue $\mathrm{T}_{3}$ during developmental and post-natal life [18, 75-77]. The $\mathrm{D}_{3} \mathrm{KO}$ mouse has central hypothyroidism (as a result of enhanced $\mathrm{T}_{3}$ signaling in the hypothalamus), growth delay and a major central nervous system phenotype including problems with survival and maturation of cone photoreceptors [77] and in cochlear development and auditory function [78], as well as aggressiveness and infertility $[75,76,79]$. However, despite the potential for multiple clinical symptoms in humans, no relevant DIO3 mutations or polymorphisms or mutations have been described in humans that are relevant for the 'second' question.

\section{Thyroid Hormone Transport Pathways}

It is clear that localized thyroid hormone deficiency in the brain could result from a variability/defect in thyroid transport across cell membranes as well. In order for $T_{3}$ to establish a transcriptional footprint in the brain, both $\mathrm{T}_{3}$ and $\mathrm{T}_{4}$ need to move across the blood-brain barrier, in and out of cells. $\mathrm{T}_{4}$ is taken up by $\mathrm{D}_{2}$-containing astrocytes and tanycytes and the resulting locally generated $\mathrm{T}_{3}$ must then exit these $\mathrm{D}_{2}$-containing cells and enter TR-containing neighboring neurons to finally trigger its transcriptional effects [80, 81]. A variability/defect in any of these steps could affect intracellular $\mathrm{T}_{3}$ content and lead to localized brain hypothyroidism. This is illustrated in patients with the Allan-Herndon-Dudley syndrome, carriers of an inactivating mutation in the X-linked MCT8 gene, a member of the MCT family that preferentially transports $\mathrm{T}_{3}$ across cell membranes and is highly expressed in several organs including the brain. Patients with this syndrome exhibit psychomotor retardation and neurological impairment, indicating brain-specific hypothyroidism during development $[82,83]$.

Other thyroid hormone transporters have been identified, including the blood-brain barrier-specific anion transporter OATP1C1, mainly expressed in capillaries throughout the brain for which $\mathrm{T}_{4}$ has a high affinity and specificity $[8,11]$. In rats, OATP1C1 mRNA and protein are up- or downregulated depending on the $\mathrm{T}_{4}$ serum levels, suggesting that this transporter plays a role in preserving physiologic concentrations of $\mathrm{T}_{4}$ (and thus $\mathrm{T}_{3}$ ) in the brain [84]. Interestingly, a clinical analysis of 141 hypothyroid participants of a randomized clinical trial revealed that OATP1C1 polymorphisms are associated with fatigue and depression but were not linked to neurocognitive dysfunction [85].

\section{The Third Question: Can a Deficiency in Brain $\mathrm{T}_{3}$ Be Restored by Treatment with Combined Levothyroxine and Liothyronine Therapy?}

There is circumstantial evidence supporting the paradigm that a variability/defect in thyroid hormone transport and/or metabolism could lead to insufficient $\mathrm{T}_{3}$ in discrete brain areas of levothyroxine-treated patients explaining their residual neurocognitive impairment despite normalization of serum $\mathrm{TSH}, \mathrm{T}_{4}$ and $\mathrm{T}_{3}$ concentrations. However, what makes this issue particularly challenging is that such a variability/defect(s) would be silenced by a functional thyroid gland, only to become clinically relevant after the onset of hypothyroidism and treatment with levothyroxine. This could be an indication that the small amounts of $\mathrm{T}_{3}$ contained in thyroid secretion would be sufficient to compensate for such a variability/defect, making it unlikely that levothyroxine alone would restore brain $\mathrm{T}_{3}$ in such individuals. In fact, even when the transport/metabolism pathways in the rat brain are fully functional, brain $\mathrm{T}_{3}$ did not increase (and remained fairly stable) in hypothyroid rats receiving a wide range (20-fold) of $\mathrm{T}_{4}$ doses [36]. In contrast, brain $\mathrm{T}_{3}$ increased progressively in hypothyroid rats treated with a much narrower range (8-fold) of $\mathrm{T}_{3}$ doses [86].

Thus, it is conceivable that administration of liothyronine could restore brain euthyroidism in hypothyroid 
individuals that remain clinically symptomatic on levothyroxine therapy. For example, if a variability/loss of function mutation in the $\mathrm{D}_{2}$ pathway or in one of the thyroid hormone transporter genes is behind the persistent psychological impairment, such patients would benefit clinically from taking liothyronine, bypassing the variability/defect. However, even if successful, such a strategy has the obvious caveat that not only the brain but all tissues would be exposed to the additional $\mathrm{T}_{3}$, thus essentially creating a state of systemic thyrotoxicosis for life [87].

A series of clinical trials indicate that a relative elevation in serum $\mathrm{T}_{3}$ can be achieved by switching patients from monotherapy with levothyroxine to a combined therapy with levothyroxine and liothyronine [87-91]. The elevation in serum $\mathrm{T}_{3}$ is variable, depending on the dose of liothyronine used. Multiple combination regimens exist, with levothyroxine:liothyronine ratios being applied at 10:1 to 5:1 [87]. A recent meta-analysis of ten such randomized controlled studies confirmed that serum TSH did not vary significantly between the monotherapy and combined therapy groups, but serum $\mathrm{FT}_{4}$ levels decreased and total serum $\mathrm{T}_{3}$ increased significantly in the patients switching to combined therapy [92]. In other regimens, relatively less $\mathrm{T}_{3}$ is used and the switch to combined therapy does not elevate serum $\mathrm{T}_{3}$ levels [93]. However, given the relatively short $\mathrm{T}_{3}$ half-life of about $12 \mathrm{~h}$ in humans, a normal serum $\mathrm{T}_{3}$ in the morning actually indicates that during the preceding $24 \mathrm{~h}$ the integrated serum $\mathrm{T}_{3}$ fluctuated at higher levels in the patients receiving combined therapy. In fact, the 24-hour profile of individuals placed on such mild combined therapies indicates that serum free $\mathrm{T}_{3}$ levels increased significantly, by about $40 \%$, within the first 4-hour post-dose, with an integrated area under the curve for serum free $\mathrm{T}_{3}$ significantly higher by about $10 \%$ [94]. In contrast, there is only a modest $16 \%$ rise in serum $\mathrm{FT}_{4}$ with no change in serum free $\mathrm{T}_{3}$ in the first 4-hour post-levothyroxine dose [94].

Despite the logic of this rationale, most randomized clinical trials (with three exceptions $[88,89,95]$ ) comparing monotherapy versus combined therapy failed to reveal a statistically significant difference in clinical outcomes [96]. The meta-analysis of eleven studies, in which 1,216 patients were randomized, found no difference in the effectiveness of monotherapy versus combined therapy symptoms such as bodily pain, depression, anxiety, fatigue, quality of life, body weight, total serum cholesterol, triglyceride levels, low-density lipoprotein, and high-density lipoprotein [96]. Yet, even when the objective methods used to assess the well-being of the patients did not uncover a meaningful change, patients did seem to prefer combined therapy [97].

The discovery of polymorphisms in the genes of the deiodinases and thyroid hormone transporters led to the obvious hypothesis that subgroups of hypothyroid patients respond differently to monotherapy versus combined therapy depending on their genetic makeup. This hypothesis was tested and the results seem encouraging, particularly in the light of a relatively large analysis of 552 individuals in the WATTS study, suggesting that the combined therapy is associated with a favorable clinical outcome in patients exhibiting the Thr $92 \mathrm{AlaD}_{2}$ polymorphism [98]. In the WATTS study, the thyroid hormone formulation used included the simultaneous reduction in the dose of levothyroxine by $50 \mu \mathrm{g} /$ day and the introduction of $10 \mu \mathrm{g} /$ day of liothyronine [98].

Notably, not all studies involving the Thr92 $\mathrm{AlaD}_{2}$ polymorphism resulted in such clear-cut results [97]. However, given that this $\mathrm{D}_{2}$ polymorphism is present in a relatively small proportion of the population on levothyroxine, previous studies are likely to have been underpowered to see this effect [97]. Likewise, no differences in appreciation for the combined therapy were observed in a relatively small sample of patients carrying OATP1C1 polymorphisms [85].

\section{Conclusions}

The vast majority of the hypothy roid patients achieve biochemical and clinical euthyroidism on thyroid hormone replacement therapy with levothyroxine alone. A small group of hypothyroid patients on monotherapy with levothyroxine remain clinically symptomatic with impaired neurocognitive functions despite normalization of serum TSH, $\mathrm{T}_{4}$ and $\mathrm{T}_{3}$ levels. This could be attributed to localized brain hypothyroidism due to a variability/defect in thyroid hormone transport and/or metabolism. Addition of liothyronine to the treatment regimen could theoretically restore brain euthyroidism and, in fact, depending on the dose of liothyronine used, patients who switched from monotherapy to combined therapy exhibited elevation in serum $\mathrm{T}_{3}$. However, a large number of clinical trials did not find improved outcomes with combined therapy. Only recently a polymorphism in the DIO2 gene, which could result in decreased $\mathrm{D}_{2}$ activity, was taken into consideration. In the WATTS trial, the largest so far, only hypothyroid patients carrying the $\mathrm{Thr} 92 \mathrm{AlaD}_{2}$ polymorphism exhibited favorable outcomes on combined therapy, indicat- 
ing that personalized medicine is catching up with thyroid disease. More studies are needed to further evaluate this question, but in the meantime the report of a slowrelease liothyronine preparation seems to offer a more stable $\mathrm{T}_{3}$ level over time $[99,100]$, opening the doors to an appealing new approach to mildly and steadily elevate serum $\mathrm{T}_{3}$ in some hypothyroid patients to offset variability/defects in thyroid hormone signaling in the brain.

\section{Acknowledgement}

The authors are grateful to Dr. Brian Kim for critically reading the manuscript and to the NIH support, DK58538, DK65055, DK77148.

\section{Disclosure Statement}

The authors have no conflicts of interest to disclose.

\section{References}

$\checkmark 1$ Aoki Y, et al: Serum TSH and total $\mathrm{T}_{4}$ in the United States population and their association with participant characteristics: $\mathrm{Na}$ tional Health and Nutrition Examination Survey (NHANES 1999-2002). Thyroid 2007;17:1211-1223.

2 Madhukar Aryal, et al: A prevalence of thyroid dysfunction in Kathmandu University Hospital, Nepal. Biomed Res 2010;21:4.

-3 Singer PA, et al: Treatment guidelines for patients with hyperthyroidism and hypothyroidism. JAMA 1995;273:808-812.

4 Larsen PR, Silva JE, Kaplan MM: Relationships between circulating and intracellular thyroid hormones: physiological and clinical implications. Endocr Rev 1981;2:87-102.

5 Murray GR: The life-history of the first case of myxoedema treated by thyroid extract. $\mathrm{Br}$ Med J 1920;i:359-360.

-6 Braverman LE, Ingbar SH, Sterling K: Conversion of thyroxine $\left(\mathrm{T}_{4}\right)$ to triiodothyronine $\left(\mathrm{T}_{3}\right)$ in athyreotic subjects. J Clin Invest 1970 49:855-864.

7 Saravanan P, et al: Psychological well-being in patients on 'adequate' doses of L-thyroxine: results of a large, controlled communitybased questionnaire study. Clin Endocrinol (Oxf) 2002;57:577-585.

${ }_{8}$ Visser WE, Friesema EC, Visser TJ: Thyroid hormone transporters: the knowns and the unknowns. Mol Endocrinol 2011;25:1-14.

9 Wu Y, Koenig RJ: Gene regulation by thyroid hormone. Trends Endocrinol Metab 2000; 11:207-211.

10 Zhang J, Lazar MA: The mechanism of action of thyroid hormones. Annu Rev Physiol 2000;62:439-466.

11 Jansen J, et al: Thyroid hormone transporters in health and disease. Thyroid 2005; 15 : 757-768.

12 Saberi M, Sterling FH, Utiger RD: Reduction in extrathyroidal triiodothyronine production by propylthiouracil in man. J Clin Invest 1975;55:218-223.

-13 Geffner DL, Azukizawa M, Hershman JM: Propylthiouracil blocks extrathyroidal conversion of thyroxine to triiodothyronine and augments thyrotropin secretion in man. J Clin Invest 1975;55:224-229.
14 Bianco AC, et al: Biochemistry, cellular and molecular biology and physiological roles of the iodothyronine selenodeiodinases. Endocr Rev 2002;23:38-89.

15 Ramadan W, et al: Type-2 iodothyronine 5'deiodinase in skeletal muscle of C57BL/6 mice. I. Identity, subcellular localization, and characterization. Endocrinology 2011; 152:3082-3092.

16 Gereben B, et al: Cellular and molecular basis of deiodinase-regulated thyroid hormone signaling. Endocr Rev 2008;29:898-938.

17 Galton VA: The roles of the iodothyronine deiodinases in mammalian development. Thyroid 2005;15:823-834.

18 Medina MC, et al: The thyroid hormone-inactivating type III deiodinase is expressed in mouse and human $\beta$-cells and its targeted inactivation impairs insulin secretion. Endocrinology 2011;152:3717-3727.

19 Peeters RP, et al: Reduced activation and increased inactivation of thyroid hormone in tissues of critically ill patients. J Clin Endocrinol Metab 2003;88:3202-3211.

20 Huang SA, Bianco AC: Reawakened interest in type III iodothyronine deiodinase in critical illness and injury. Nat Clin Pract Endocrinol Metab 2008;4:148-155.

21 Braverman LE, et al: Effects of replacement doses of sodium L-thyroxine on the peripheral metabolism of thyroxine and triiodothyronine in man. J Clin Invest 1973;52: 1010-1017.

22 Stock JM, Surks MI, Oppenheimer JH: Replacement dosage of L-thyroxine in hypothyroidism. A re-evaluation. N Engl J Med 1974; 290:529-533.

23 Jonklaas J, et al: Triiodothyronine levels in athyreotic individuals during levothyroxine therapy. JAMA 2008;299:769-777.

24 Gullo D, et al: Levothyroxine monotherapy cannot guarantee euthyroidism in all athyreotic patients. PLoS One 2011;6:e22552.

25 Oppenheimer JH, Schwartz HL, Surks MI: Determination of common parameters of iodothyronine metabolism and distribution in man by noncompartmental analysis. J Clin Endocrinol Metab 1975;41:319-324.
26 Baqui MM, et al: Distinct subcellular localization of transiently expressed types 1 and 2 iodothyronine deiodinases as determined by immunofluorescence confocal microscopy. Endocrinology 2000;141:4309-4312.

27 Friesema EC, et al: Thyroid hormone transport by the human monocarboxylate transporter 8 and its rate-limiting role in intracellular metabolism. Mol Endocrinol 2006;20: 2761-2772.

28 Schneider MJ, et al: Targeted disruption of the type 2 selenodeiodinase gene (DIO2) results in a phenotype of pituitary resistance to $\mathrm{T}_{4}$. Mol Endocrinol 2001;15:2137-2148.

29 Hall JA, Bianco AC: Triumphs of the thyroid despite lesser conversion. Endocrinology 2009;150:2502-2504.

30 Christoffolete MA, et al: Mice with impaired extrathyroidal thyroxine to $3,5,3^{\prime}$-triiodothyronine conversion maintain normal serum 3,5,3'-triiodothyronine concentrations. Endocrinology 2007;148:954-960.

31 Galton VA, et al: Life without $\mathrm{T}_{4}$ to $\mathrm{T}_{3}$ conversion: studies in mice devoid of the $5^{\prime}$ deiodinases. Endocrinology 2009;150:29572963.

32 Bianco AC, Kim BW: Deiodinases: implications of the local control of thyroid hormone action. J Clin Investigation 2006;116:25712579.

33 Campos-Barros A, et al: Phenolic and tyrosyl ring iodothyronine deiodination and thyroid hormone concentrations in the human central nervous system. J Clin Endocrinol Metab 1996;81:2179-2185.

34 Peeters RP, et al: Tissue thyroid hormone levels in critical illness. J Clin Endocrinol Metab 2005;90:6498-6507.

35 Kester MH, et al: Iodothyronine levels in the human developing brain: major regulatory roles of iodothyronine deiodinases in different areas. J Clin Endocrinol Metab 2004;89: 3117-3128.

36 Escobar-Morreale HF, et al: Replacement therapy for hypothyroidism with thyroxine alone does not ensure euthyroidism in all tissues, as studied in thyroidectomized rats. J Clin Invest 1995;96:2828-2838. 
37 Andersen S, et al: Biologic variation is important for interpretation of thyroid function tests. Thyroid 2003;13:1069-1078.

-38 Bianco AC, Silva JE: Cold exposure rapidly induces virtual saturation of brown adipose tissue nuclear $\mathrm{T}_{3}$ receptors. Am J Physiol 1988;255:E496-E503.

-39 Dumitrescu AM, et al: Mutations in SECISBP2 result in abnormal thyroid hormone metabolism. Nat Gen 2005;37:12471252.

40 Berry MJ, et al: Physiological and genetic analyses of inbred mouse strains with a type I iodothyronine 5 '-deiodinase deficiency. J Clin Invest 1993:92:1517-1528.

-41 Schneider MJ, et al: Targeted disruption of the type 1 selenodeiodinase gene (Diol) results in marked changes in thyroid hormone economy in mice. Endocrinology 2006; 147 : 580-589.

42 Dayan CM, Panicker V: Novel insights into thyroid hormones from the study of common genetic variation. Nat Rev Endocrinol 2009;5:211-218.

43 De Jong FJ, et al: The association of polymorphisms in the type 1 and 2 deiodinase genes with circulating thyroid hormone parameters and atrophy of the medial temporal lobe. J Clin Endocrinol Metab 2007;92:636640.

-44 De Jesus LA, et al: The type 2 iodothyronine deiodinase is essential for adaptive thermogenesis in brown adipose tissue. J Clin Invest 2001;108:1379-1385.

$\checkmark 45$ Christoffolete MA, et al: Mice with targeted disruption of the DIO2 gene have cold-induced overexpression of the uncoupling protein 1 gene but fail to increase brown adipose tissue lipogenesis and adaptive thermogenesis. Diabetes 2004;53:577-584.

46 Hall JA, et al: Absence of thyroid hormone activation during development underlies a permanent defect in adaptive thermogenesis. Endocrinology 2010;151:4573-4582.

-47 Ng L, et al: Hearing loss and retarded cochlear development in mice lacking type 2 iodothyronine deiodinase. Proc Natl Acad Sci USA 2004;101:3474-3479.

$\checkmark 48$ Bassett JH, et al: Optimal bone strength and mineralization requires the type 2 iodothyronine deiodinase in osteoblasts. Proc Natl Acad Sci USA 2010;107:7604-7609.

49 Marsili A, et al: Type II iodothyronine deiodinase provides intracellular 3,5,3'-triiodothyronine to normal and regenerating mouse skeletal muscle. Am J Physiol Endocrinol Metab 2011;301:E818-E824.

50 Dentice M, et al: The FoxO3/type 2 deiodinase pathway is required for normal mouse myogenesis and muscle regeneration. J Clin Invest 2011;120:4021-4030.

51 Barca-Mayo O, et al: Role of type 2 deiodinase in response to acute lung injury in mice. Proc Natl Acad Sci USA 2011;108:E1321E1329.
52 Crantz FR, Silva JE, Larsen PR: Analysis of the sources and quantity of 3,5,3'-triiodothyronine specifically bound to nuclear receptors in rat cerebral cortex and cerebellum. Endocrinology 1982;110:367-375.

53 Mentuccia D, et al: Association between a novel variant of the human type 2 deiodinase gene Thr92Ala and insulin resistance: evidence of interaction with the Trp64Arg variant of the $\beta_{3}$-adrenergic receptor. Diabetes 2002;51:880-883.

54 Canani LH, et al: The type 2 deiodinase A/G (Thr92Ala) polymorphism is associated with decreased enzyme velocity and increased insulin resistance in patients with type 2 diabetes mellitus. J Clin Endocrinol Metab 2005;90:3472-3478.

55 Dora JM, et al: Association of the type 2 deiodinase Thr92Ala polymorphism with type 2 diabetes: case-control study and metaanalysis. Eur J Endocrinol 2010;163:427434.

56 Guo TW, et al: Positive association of the DIO2 (deiodinase type 2) gene with mental retardation in the iodine-deficient areas of China. J Med Genet 2004;41:585-590.

57 Gumieniak O, et al: Ala92 type 2 deiodinase allele increases risk for the development of hypertension. Hypertension 2007;49:461466.

58 Meulenbelt I, et al: Identification of DIO2 as new susceptibility locus for symptomatic Osteoarthritis. Hum Mol Genet 2008; 17: 1867-1875.

$59 \mathrm{He}$ B, et al: Association of genetic polymorphisms in the type II deiodinase gene with bipolar disorder in a subset of Chinese population. Prog Neuropsychopharmacol Biol Psychiatry 2009;33:986-990.

60 Grineva E, et al: Type 2 deiodinase Thr92Ala polymorphism impact on clinical course and myocardial remodeling in patients with Graves' disease. Cell Cycle 2009;8:25652569.

61 Heemstra KA, et al: The type 2 deiodinase Thr92Ala polymorphism is associated with increased bone turnover and decreased femoral neck bone mineral density. J Bone Miner Res 2010;25:1385-1391.

62 Ma SF, et al: Type 2 deiodinase and host responses of sepsis and acute lung injury. Am J Respir Cell Mol Biol 2011;45:1203-1211.

63 Peeters RP, et al: Polymorphisms in thyroid hormone pathway genes are associated with plasma TSH and iodothyronine levels in healthy subjects. J Clin Endocrinol Metab 2003;88:2880-2888.

64 Larsen PR: Type 2 iodothyronine deiodinase in human skeletal muscle: new insights into its physiological role and regulation. J Clin Endocrinol Metab 2009;94:1893-1895.

65 Torlontano M, et al: Type 2 deiodinase polymorphism (Thr92Ala) predicts L-thyroxine dose to achieve target TSH levels in thyroidectomized patients. J Clin Endocrinol Metab 2008;93:910-913.
66 Butler PW, et al: The Thr92Ala 5'-type 2 deiodinase gene polymorphism is associated with a delayed triiodothyronine secretion in response to the thyrotropin-releasing hormone-stimulation test: a pharmacogenomic study. Thyroid 2011;20:1407-1412.

67 Canani LH, et al: Type 2 deiodinase Thr92Ala polymorphism is not associated with arterial hypertension in type 2 diabetes mellitus patients. Hypertension 2007;49:e47-e48.

68 Grarup N, et al: Studies of the common DIO2 Thr92Ala polymorphism and metabolic phenotypes in 7342 Danish white subjects. J Clin Endocrinol Metab 2007;92:363-366.

-69 Gumieniak O, Williams GH: Response to type 2 deiodinase Thr92Ala polymorphism is not associated with arterial hypertension in type 2 diabetes mellitus patients. Hypertension 2007;49:e47-e48.

70 Heemstra KA, et al: Thr92Ala polymorphism in the type 2 deiodinase is not associated with $\mathrm{T}_{4}$ dose in athyroid patients or patients with Hashimoto thyroiditis. Clin Endocrinol (Oxf) 2009;71:279-283.

-71 Nair S, et al: Association analyses of variants in the DIO2 gene with early-onset type $2 \mathrm{di}$ abetes mellitus in Pima Indians. Thyroid 2012;22:80-87.

72 Van der Deure WM, et al: Impact of thyroid function and polymorphisms in the type 2 deiodinase on blood pressure: the Rotterdam Study and the Rotterdam Scan Study. Clin Endocrinol (Oxf) 2009;71:137-144

73 Mentuccia D, et al: The Thr92Ala deiodinase type 2 (DIO2) variant is not associated with type 2 diabetes or indices of insulin resistance in the old order of Amish. Thyroid 2005; 15:1223-1227.

74 Peeters RP, van der Deure WM, Visser TJ: Genetic variation in thyroid hormone pathway genes; polymorphisms in the TSH receptor and the iodothyronine deiodinases. Eur J Endocrinol 2006;155:655-662.

75 Hernandez A, et al: Type 3 deiodinase is critical for the maturation and function of the thyroid axis. J Clin Invest 2006;116:476-484.

76 Hernandez A, et al: Type 3 deiodinase deficiency results in functional abnormalities at multiple levels of the thyroid axis. Endocrinology 2007; 148:5680-5687.

$77 \mathrm{Ng} \mathrm{L}$, et al: Type 3 deiodinase, a thyroid-hormone-inactivating enzyme, controls survival and maturation of cone photoreceptors. J Neurosci 2010;30:3347-3357.

$78 \mathrm{Ng} \mathrm{L}$, et al: A protective role for type 3 deiodinase, a thyroid hormone-inactivating enzyme, in cochlear development and auditory function. Endocrinology 2009; 150:19521960.

79 Hernandez A, et al: Type 3 deiodinase deficiency causes spatial and temporal alterations in brain $\mathrm{T}_{3}$ signaling that are dissociated from serum thyroid hormone levels. Endocrinology 2010;151:5550-5558. 
80 Freitas BC, et al: Paracrine signaling by glial cell-derived triiodothyronine activates neuronal gene expression in the rodent brain and human cells. J Clin Invest 2010;120: 2206-2217.

81 Mohacsik P, et al: Thyroid hormone and the neuroglia: both source and target. J Thyroid Res 2011;2011:215718.

82 Dumitrescu AM, et al: A novel syndrome combining thyroid and neurological abnormalities is associated with mutations in a monocarboxylate transporter gene. Am J Hum Genet 2004;74:168-175.

83 Friesema EC, et al: Association between mutations in a thyroid hormone transporter and severe X-linked psychomotor retardation. Lancet 2004;364:1435-1437.

-84 Sugiyama D, et al: Functional characterization of rat brain-specific organic anion transporter (Oatp14) at the blood-brain barrier: high affinity transporter for thyroxine. J Biol Chem 2003;278:43489-43495.

85 Van der Deure W, Appelhof BC, Peeters RP, Wiersinga WM, Wekkig EM, Huyser J, Schene AH, Tijssen JGP, Hoogendijk WJG, Visser TJ, Fliers E: Polymorphism in the brain-specific thyroid hormone transporter OATP-C1 are associated with fatigue and depression in hypothyroid patients. Clin Endocrinol 2008;69:8.

-86 Escobar-Morreale HF, et al: Regulation of iodothyronine deiodinase activity as studied in thyroidectomized rats infused with thyroxine or triiodothyronine. Endocrinology 1997;138:2559-2568.

87 Appelhof BC, et al: Combined therapy with levothyroxine and liothyronine in two ratios, compared with levothyroxine monotherapy in primary hypothyroidism: a double-blind, randomized, controlled clinical trial. J Clin Endocrinol Metab 2005;90: 2666-2674.
88 Bunevicius R, et al: Thyroxine vs. thyroxine plus triiodothyronine in treatment of hypothyroidism after thyroidectomy for Graves' disease. Endocrine 2002;18:129-133.

89 Bunevicius R, et al: Effects of thyroxine as compared with thyroxine plus triiodothyronine in patients with hypothyroidism. N Engl J Med 1999;340:424-429.

90 Valizadeh M, et al: Efficacy of combined levothyroxine and liothyronine as compared with levothyroxine monotherapy in primary hypothyroidism: a randomized controlled trial. Endocr Res 2009;34:80-89.

91 Rodriguez T, et al: Substitution of liothyronine at a 1:5 ratio for a portion of levothyroxine: effect on fatigue, symptoms of depression, and working memory versus treatment with levothyroxine alone. Endocr Pract 2005;11:223-233.

$92 \mathrm{Ma} \mathrm{C}$, et al: Thyroxine alone or thyroxine plus triiodothyronine replacement therapy for hypothyroidism. Nucl Med Commun 2009;30:586-593.

93 Saravanan P, et al: Partial substitution of thyroxine $\left(\mathrm{T}_{4}\right)$ with tri-iodothyronine in patients on $\mathrm{T}_{4}$ replacement therapy: results of a large community-based randomized controlled trial. J Clin Endocrinol Metab 2005; 90:805-812.

94 Saravanan P, et al: Twenty-four hour hormone profiles of TSH, free $\mathrm{T}_{3}$ and free $\mathrm{T}_{4}$ in hypothyroid patients on combined $\mathrm{T}_{3} / \mathrm{T}_{4}$ therapy. Exp Clin Endocrinol Diabetes 2007; 115:261-267.
95 Nygaard B, et al: Effect of combination therapy with thyroxine $\left(\mathrm{T}_{4}\right)$ and $3,5,3^{\prime}$ triiodothyronine versus $\mathrm{T}_{4}$ monotherapy in patients with hypothyroidism, a doubleblind, randomised cross-over study. Eur J Endocrinol 2009;161:895-902.

96 Grozinsky-Glasberg S, et al: Thyroxine-triiodothyronine combination therapy versus thyroxine monotherapy for clinical hypothyroidism: meta-analysis of randomized controlled trials. J Clin Endocrinol Metab 2006;91:2592-2599.

97 Appelhof BC, et al: Polymorphisms in type 2 deiodinase are not associated with wellbeing, neurocognitive functioning, and preference for combined thyroxine/3,5,3'triiodothyronine therapy. J Clin Endocrinol Metab 2005;90:6296-6299.

98 Panicker V, et al: Common variation in the DIO2 gene predicts baseline psychological well-being and response to combination thyroxine plus triiodothyronine therapy in hypothyroid patients. J Clin Endocrinol Metab 2009;94:1623-1629.

99 Hennemann G, et al: Thyroxine plus lowdose, slow-release triiodothyronine replacement in hypothyroidism: proof of principle. Thyroid 2004;14:271-275.

100 Frumess RD, Larsen PR: Correlation of serum triiodothyronine $\left(\mathrm{T}_{3}\right)$ and thyroxine $\left(\mathrm{T}_{4}\right)$ with biologic effects of thyroid hormone replacement in propylthiouraciltreated rats. Metabolism 1975;24:547-554.

101 Dentice M, et al: The Hedgehog-inducible ubiquitin ligase subunit WSB-1 modulates thyroid hormone activation and PTHrP secretion in the developing growth plate. Nat Cell Biol 2005;7:698-705.

102 Callebaut I, et al: The iodothyronine selenodeiodinases are thioredoxin-fold family proteins containing a glycoside hydrolase clan GH-A-like structure. J Biol Chem 2003;278:36887-36896. 